\title{
Implementation of Merdeka Belajar in the Perspective of Islamic Education at SMK NU Mekanika Buntet Pesantren Cirebon
}

\author{
Fahad Achmad Sadat \\ ${ }^{1}$ STIT Buntet Pesantren Cirebon Cirebon \\ *Coresponding Author \\ Email : fahad@stit-buntepesantren.ac.id
}

\begin{abstract}
The Freedom of learning Policy issued by the Minister of Education and Culture (Mendikbud) Nadiem Makarim on November 22, 2019 changed many things in the national education process. Starting from learning practices that place more emphasis on student interests, the assessment process that no longer focuses on cognitive abilities and is handed over to the head of the education unit, to the process of preparing the Lesson Plan (RPP) which is simpler.In the world of Islamic education, this concept is not new. Since classical times, education in Islam has emphasized independence. However, the concept is not institutionalized. Therefore, when the Minister of Education and Culture Nadiem Makarim issued this policy, it seemed as if it was a new thing. NU Mekanika a Islamic Vocational School is preparing to apply the concept of Independent Learning. However, its implementation is not optimal. There are two obstacles. First, because this policy is still new, schools still need examples or comparative studies with other schools that have implemented this policy first. Second, the Covid-19 pandemic, which has lasted for almost 2 years, has made the teaching and learning process more carried out online
\end{abstract}

Keywords: Merdeka Belajar, Islamic Education

\section{INTRODUCTION}

Education is something that can cause the capacity or ability of the community to develop, can foster desire, and arouse the ambition of a generation of nations to explore various desires and be able to develop them optimally in the process of developing the interests of society as a whole without being interspersed with complications (Mulyasa, 2011: 5). . M. Fahim Tharaba (2019) emphasized that education essentially functions as a place for knowledge transfer, value transfer, it also functions to maintain and develop traditions and noble cultures in a society through the process of personality formation so that they become mature human beings who are able to stand alone in the culture and surrounding community.

In the 4.0 revolution period, the transformation of social structures is changing rapidly, social relations depend on technology, the loss of some categories of work, citizens have equal opportunities and have strong competitiveness. The period of the industrial revolution 4.0 has challenges as well as opportunities for educational institutions.

Learning as the development of competence to think, play a role, and live and become part of the world's citizens. The industrial revolution 4.0 also provides new opportunities and challenges for every country in order to survive in competition in a highly competitive global world (Yusro, 2018: 9). Provisions for advancing and growing educational institutions must have the energy of innovation, and be able to work together.

During the Industrial Revolution 4.0, the learning system is expected to be able to realize that students have skills that are able to think critically and solve problems, are creative, innovative, communicate and collaborate skills. In addition, expertise in finding, managing and delivering data and skills in using data and technology are needed. With the hope that students 
can face a good future, educational development should be applicable, adaptive and anticipatory (Mozzain, 2005: 78).

Education has so far been less successful in creating these competencies. The reason, there is no freedom in learning. Students are only required to memorize all learning materials and are limited by various learning rules, so that their critical and creative spirit is imprisoned. Meanwhile, educators are burdened with a pile of administrative tasks that neglect their main task, namely educating. In fact, the essence of identity is the development of creativity and human personal expression (Herly Janet Lesilolo, 2015:11-15).

Then, the Independent Learning policy came out. There are four main policies in Merdeka Learning, namely reforming the National Standard School Examination (USBN) sector, National Examination (UN), Learning Implementation Plans (RPP), and the Zoning Regulations for Admission of New Students (PPDB). USBN is replaced by an assessment exam. The UN was discontinued and replaced with a minimum competency assessment, the lesson plans were shortened to one page, and the PPDB zone was made more flexible.

With this policy, schools can further develop a curriculum that is in accordance with the school's vision and mission. Because it is no longer tied to the final destination of the UN and USBN. Teachers are also more independent in determining the choice of material to be given to students. Of course, the selection of this material must go through observation first to determine which is really in accordance with the conditions and situations and which can support the potential and needs of students.

With the Freedom of Learning, student involvement in learning will increase. They will be happier while studying. Happy students tend to be more active in learning so that their contribution increases significantly than those who are not happy (Delpianus Piong, 2020: 291).

In Islam, the concept of independence is highly respected. God gave humans freedom to carry out any activity they wanted. However, every choice of freedom has its consequences. The good will get good, and the bad will get bad. This freedom also exists in the world of Islamic education.

Freedom of Learning is actually not a new thing in the world of Islamic education. In pesantren, for example, in terms of evaluation, it is commonplace to create a separate evaluation system that is different from the system determined by the government. Usually called imtihan. The material tested is in accordance with what is given to students and the competencies determined by the pesantren.

\section{RESEARCH METHODS}

This research was conducted using a qualitative approach. The method used is descriptive analysis. Location and source of research data at SMK NU Mekanika Buntet Pesantren Cirebon Cirebon. Techniques and research instruments using interviews and literature. While the analysis technique is done through data reduction, data display and drawing conclusions

\section{RESULTS AND DISCUSSION}

In the Kamus Besar Bahasa Indonesia (KBBI) of the Ministry of Education and Culture, "merdeka" means free, independent, not affected or free from demands, not bound, not dependent on people. While "learning" means trying to gain intelligence or knowledge, practice, change behavior or responses caused by experience. 
If it is drawn from the meaning of the two words, "freedom" and "learning"; Independent Learning is learning that is free, free and not bound, which moves students to develop their full potential in order to achieve intellectual, moral, and other skills.

There are three aspects to learning. Namely (1) there is a change in behavior due to education and training as well as experience, (2) there is education and training, (3) there is experience (Seto Mulyadi, 2017:34). Gagne states, learning is an internal intellectual mental activity (Jamaludin, 2015:9). The actualization of learning activities is the process of operating the child's mental-intellectual. Mc Geoch (Bulgeski, 1956: 459-469) defines learning as "a change in performance as a result of practice". Learning is a change in appearance as a result of practice. According to Piaget, learning is a process of student interaction with the environment that is always changing and is carried out continuously (Abuddin Nata, 2009:99).

Freedom to Learn, initiated by Nadiem Makarim, became a policy that was first announced on Teacher's Day, November 25, 2019. Three days earlier, namely November 22, 2019, the manuscript was uploaded on the official website of the Ministry of Education and Culture and went viral on social media. With Independent Learning, it is hoped that it will create a happy learning atmosphere, both for students and teachers. The teacher creates a learning process that can make students more creative to gain knowledge in depth and create a happy learning atmosphere.

The following are concepts that can be put into practice in Merdeka Learning:

- Commitment to Goals A person's commitment to independent learning is his persistence towards goals that are meaningful to him. Setting clear goals in learning is an important aspect.

- Independent Learning In education, independence is called Self Regulated Learning (SRL). According to Suhendri (2012), independence is a positive mental attitude of an individual for the convenience of carrying out planning activities to achieve goals by positioning or conditioning himself so that he can evaluate himself and his environment. Independence is very important for students. Independent students receive learning materials more quickly so that they shape the character of students for the better (Diniyah, 2018:15).

- Fostering Social Emotional Learning (SEL) Casel defines SEL as the process through which children determine and apply knowledge, and skills effectively to understand/regulate emotions, set positive goals, and feel or show empathy for others (Haleludin, 2019 :6).

The foundation for Independent Learning is Law Number 20 of 2003 concerning the National Education System and Circular Letter (SE) of the Minister of Education and Culture Number 1 of 2020 concerning the Free Learning Policy in Determining Student Graduation and Admission of New Students for the 2020/2021 Academic Year.

According to the Ministry of Education and Culture, independent learning is giving freedom and autonomy to educational institutions and independence from bureaucratization, lecturers are freed from complicated bureaucracy and students are given the freedom to choose the fields they like (High, 2020). The Ministry of Education and Culture's version of independent learning can be interpreted as the application of the curriculum in the learning process that demands fun with the development of innovative and creative thinking by the teacher. This can foster a positive attitude of students in responding to learning (Saleh, 2020: $51-56)$.

\section{Islamic Education Perspective}

In Arabic, education is juxtaposed with three terms, namely tarbiyah, ta'lim and ta'dib. All three have in common, both textually and contextually. In terms of tarbiyah, education can be interpreted as a deliberate and conscious act, planned, gradual or gradual in order to imitate 
the characteristics of Rabbaniah. Ta'lim is defined as teaching or providing information or transmitting knowledge. While ta'dib is defined as guidance and gradual recognition of the creator.

Islamic education has different characteristics from general education. Some Islamic education experts such as Yusuf Qardhawi stated, Islamic education is the education of a whole person, mind and heart, spiritual and physical, morals and skills. Islamic education prepares humans for life, both in security and in war, and prepares them to face society with all its good and evil, sweet and bitter (Yusuf Qardawi, 1980:39).

Haedar Nashir in Mohamad Ali (2017:17) said, Islamic education is an effort to make humans capable of carrying out their role as caliphate on earth (caliph fil ardl). Being a caliph means that humans, both individually and collectively, function as actors in the history of change to prosper and build the main living civilization, which distinguishes human life from the lives of other God's creatures.

If it is associated with Islamic education, Merdeka Learning is identical with liberation education. Islam places great emphasis on liberation education. We can find the basic concept of freedom in Islam from basic human freedom, including in choosing a religion. In Q.S. AlKafirun verse 6 Allah says: Meaning: "To you is your religion, and to me is my religion.".

\section{The Merdeka Belajar from the Perspective of Islamic Education}

The term independence in Arabic is called "al-Istiqlāl". That is, free and free from all forms of ties and control of other parties. Another word for this meaning is "Al-Hurriyyah", which is commonly translated freedom. From this word, the word "al-Tahrir" is formed which means liberation. A free person is called "al-hurr", the opposite of "al-'abd" (slave). The word "al-hurriyah" is what is often interpreted in the Qur'an, not the word "Istiqlal". However, of course, independence in Islam does not mean without limitations.

Freedom in Islam is not arbitrary. The concept of freedom in Islam is known as endeavor. The term is one root with khair, which means good. So, humans are given the freedom to choose but must contain goodness in it. If freedom is not accompanied by goodness, it is wrong, it is freedom that is not right. Independence is one of the basic rights for humans. According to Hamka, independence is the spirit of human life and the milestone of its glory (Hamka, 1990:161).

Humans are born free. He was born into the world knowing no difference. Therefore, in life, humans should still be people. The freedom inherent in humans is limited. Free to be free does not mean everything is free to do. Freedom in Islam is limited by law and sharia. These limitations can be found in the Qur'an and hadith.

According to Hamka, there are three main essences of independence, namely freedom of irada (willingness), freedom of mind or freedom of expression, and freedom of spirit, namely freedom from fear. The nature of this independence can be used as a basis in applying the Independent Learning process.

\section{Independent Students and Independent Teachers}

So far, the education system is considered to still have not provided room for creativity and student curiosity. Therefore, according to Buya Syafi'i Ma'arif, the proposed educational system and orientation is an educational model that can liberate (read: liberate) humans from a culture that is all verbal, mechanistic and superficial (Ahmad Syafi'i Ma'arif, 1993). :148).

To shape students into complete human beings who have independence, we can see the criteria of students expressed by Samsul Nizar (2005, 48-50): (1) Students are not miniature adults but have their own world; (2) Learners have a period of development and growth; (3) Students are creatures of God who have individual differences due to both innate and environmental factors; 
(4) Students are the two main elements, physical and spiritual, the physical element has physical power and the spiritual element has the power of reason, conscience and lust; (5) Learners are human beings who have potential or nature that can be developed and developed dynamically. Positioning independent students is to make them as subjects in the learning process. Give them space for those who make their own decisions in the learning process. Making your own decisions is one of the elements in the Independent Learning process.

In Islamic education, Prophet Muhammad SAW is often used as an example of how to be an ideal teacher. He is not only a mudarris, but also a convert, muzakki, murabbi, mu'addib, murshid and mutli. So, the responsibility of an educator is very big, because educators are not only obliged to transfer knowledge, but also have to maintain and preserve the physical and spiritual aspects of students.

Implementation of Independent Learning at NU Mechanics Vocational School, There are four main Freedom Learning policies, namely those relating to the National Standardized School Examination (USBN), the National Examination (UN), Learning Implementation Plans (RPP), and the Zoning Regulations for Admission of New Students (PPDB). Of the four, two relate to the evaluation process, namely the UN and USBN. The UN has now been removed.

Now, the evaluation process is fully returned to the school. Evaluation in Independent Learning is no longer generalized, but is carried out according to the achievements and abilities of students in absorbing the material. The policy is in line with Islamic Education.

As contained in Surah Al-Zalzalah and other verses in the Qur'an which show the existence of freedom in terms of acting in the world, even though there are rewards according to the choices made in the world (Ano Suharna, 2016: 49-68). This verse teaches us about freedom or independence in acting and being responsible for all the actions and choices we make. Because, no matter how small the action, will get a reply.

In the learning analogy, students are freed in getting information and learning. Because, everything will be assessed comprehensively by the school, not by the government (Eva Dwi Kumala Sari, 2017:17-28).

In Islamic Education, evaluation can be found in several terms. Such as al-hisab, alimtihan, and al-ihktibar (Suharna, 2016:59-61). Some hadiths also explain about evaluation. The Prophet often evaluated the memorization of his companions by telling him to read verses from the Qur'an in front of him. The Prophet corrected their erroneous memorization and reading. The Prophet also evaluated the ability of the Companions to be envoys to an area to teach Islam.

SMK NU Mekanika Buntet Pesantren Cirebon carries the vision of a vocational school that is religious, intelligent, independent and has qualified or skillful skills and has noble character. This vision is implemented in various programs, such as school culture, religious activities, extracurricular activities, and so on. Islamic school culture can be seen from the use of uniforms, in which all students and teachers are required to wear Islamic uniforms; habits before and after study; the cultivation of cleanliness is part of the faith; and habituation of greetings, smiles, greetings, courtesy, and courtesy.

Religious activities such as Dhuha, Dzuhur and Asr prayer activities in congregation, muhadharah activities, providing hadith and mahfudzat material outside of PAI learning materials, tahfidz, moral development, and so on.

Islamic activities are also reflected in the existence of extracurricular hadrah and student morals who usually carry out various religious competitions and study activities both on weekdays and in the month of Ramadan.

With regard to the implementation of the Freedom of Learning policy, the Principal of the NU Mekanika Buntet Pesantren Cirebon Vocational School, stated that teachers have been given training and training. Other trainings are being prepared. According to him, in order for 
the implementation of Merdeka Learning to run well, teachers must also be provided with new materials and improve their competence. "The school will bring in competent or practical resource persons to strengthen the potential of teachers, either through training or workshops. For students, learning must be in accordance with their competence. We will apply it later," he said.

In addition, the NU Mekanika Buntet Vocational School of Pesantren Cirebon will also conduct comparative studies to other schools that have implemented the Independent Learning policy. The goal is that the NU Mekanika Buntet Pesantren Cirebon Vocational School can understand the concept and how to implement it from schools that have implemented Merdeka Learning first. That way, when implemented at the NU Mekanika Buntet Vocational School of the Cirebon Islamic Boarding School, the Independent Learning policy can be carried out carefully.

With regard to freedom of choice, SMK NU Mekanika Buntet Pesantren Cirebon, like vocational schools that have Islamic characteristics, tries to provide fardhu a'in knowledge contained in PAI material which is also applied in school culture, such as providing hours for memorizing the Qur'an., hadith and mahfudzot, habituation of Dhuha, Dhuhur and Asr prayers in congregation, muhadharah activities and Islamic motivation every morning. These activities are controlled through a worship monitoring book that must be owned by every student.

The Islamic Education Institute Foundation (YLPI), which oversees the NU Mekanika Vocational School, also requires boarding schools for students in YLPI lodges. Various religious studies were given to students who were also students from the NU Mekanika Vocational School. With this obligation, it is hoped that the fardhu a'in sciences can be properly mastered and practiced in daily life, so that the main goals of national education and the vision and mission of the NU Mekanika Vocational School which produce a religious, independent, skilled and noble generation can be achieved. .

Another thing that should not be ignored in Merdeka Learning is the evaluation process. There are several assignment models that are given to students to determine learning outcomes, some are in the form of multiple choice questions, some provide essays, portfolios, or in the form of projects and products.

For scheduled evaluations, such as Mid-Semester and End Semester Assessments, they are carried out with two different forms of questions. Questions for PTS use essays, and for the Final Semester Assessment with multiple choice questions. As for productive content, there is a competency test. Teachers are given the freedom to make their own questions, according to the material that has been delivered. However, the majority still fit the syllabus. For general lessons, in everyday assessments there is no standard reference for questions or assignments. It all depends on the creativity of the teacher. When learning takes place face-to-face, various assessment systems and practices are often applied by teachers.

However, this has decreased in effectiveness since online learning. The next Free Learning Policy that is being prepared is the implementation of a national assessment. Several teachers have been prepared to become committees and several students have been selected to take part in the national assessment. Teachers of Indonesian and Mathematics, already know about this assessment plan. They have also received guidelines regarding the preparation of questions and the draft agenda for this assessment process

\section{CONCLUSION}

Freedom of Learning in an Islamic perspective can be concluded as an internal process that moves students to use all their natural, cognitive, affective, and psychomotor potentials independently, in order to become human beings who have various intellectual capabilities, 
skills, morality, carry the mission of rahmatan lil a 'lamin with the aim of worshiping Allah SWT.

All the learning process is carried out by upholding the principle of independence as a creature of God. The implementation of Independent Learning at the Insan Mulia Islamic Vocational School, both concepts and policies, has been attempted to be implemented optimally. However, due to various obstacles, such as the new Free Learning policy and the Covid-19 pandemic that has hit for almost two years, this has become a challenge in itself. Therefore, more serious and consistent efforts are needed as well as with careful and sustainable planning to maximize the implementation of this independent learning.

\section{REFERENCES}

Hermino, Agustinus. 2020. Merdeka Belajar di Era Global dalam Perspektif Manajemen Pendidikan. Yogyakarta: Pustaka Pelajar.

Holosko, M. J., dkk. 2018. "Human Behavior in the Social Environment". Person-Centered Theory. John Wiley \& Sons Inc. Vol. 2, 2008.

Kumala Sari, Eva Dwi. 2017. "Isu-Isu Kritis dalam pendidikan: Lemahnya Kualitas Tes Ujian Akhir Sekolah Berstandar Nasional (UASBN) di Tingkat Sekolah Dasar”. Almarhal. Jurnal Pendidikan Islam 1, No. 1 (2017).

D. J. P. Tinggi (2020). Buku Panduan Merdeka Belajar-Kampus Merdeka. Direktorat Jenderal Pendidikan Tinggi Kementerian Pendidikan dan Kebudayaan.

Din Wahyudin. (2014). Manajemen Kurikulum, Bandung: PT. Remaja Rosda Karya.

E. S. Sherly. Dharma dan H. B. Sihombing. (2020). Merdeka Belajar: Kajian Literatur. UrbanGreen Conference Proceeding Library. 